\title{
Front Matter: Volume 8344
}

, "Front Matter: Volume 8344," Proc. SPIE 8344, Nanosensors, Biosensors, and Info-Tech Sensors and Systems 2012, 834401 (24 April 2012); doi: 10.1117/12.964453

Event: SPIE Smart Structures and Materials + Nondestructive Evaluation and Health Monitoring, 2012, San Diego, California, United States 


\title{
PROCEEDINGS OF SPIE
}

\section{Nanosensors, Biosensors, and Info-Tech Sensors and Systems 2012}

\author{
Vijay K. Varadan \\ Editor \\ 12-15 March 2012 \\ San Diego, California, United States \\ Sponsored by \\ SPIE \\ Cosponsored by \\ American Society of Mechanical Engineers (United States) \\ Cooperating Organizations \\ Intelligent Materials Forum (Japan) \\ Jet Propulsion Laboratory (United States) \\ National Science Foundation (United States) \\ Published by \\ SPIE
}


The papers included in this volume were part of the technical conference cited on the cover and title page. Papers were selected and subject to review by the editors and conference program committee. Some conference presentations may not be available for publication. The papers published in these proceedings reflect the work and thoughts of the authors and are published herein as submitted. The publisher is not responsible for the validity of the information or for any outcomes resulting from reliance thereon.

Please use the following format to cite material from this book:

Author(s), "Title of Paper," in Nanosensors, Biosensors, and Info-Tech Sensors and Systems 2012. edited by Vijay K. Varadan, Proceedings of SPIE Vol. 8344 (SPIE, Bellingham, WA, 2012) Article CID Number.

ISSN 0277-786X

ISBN 9780819490018

Published by

SPIE

P.O. Box 10, Bellingham, Washington 98227-0010 USA

Telephone +1 3606763290 (Pacific Time) · Fax +1 3606471445

SPIE.org

Copyright (C) 2012, Society of Photo-Optical Instrumentation Engineers

Copying of material in this book for internal or personal use, or for the internal or personal use of specific clients, beyond the fair use provisions granted by the U.S. Copyright Law is authorized by SPIE subject to payment of copying fees. The Transactional Reporting Service base fee for this volume is $\$ 18.00$ per article (or portion thereof), which should be paid directly to the Copyright Clearance Center (CCC), 222 Rosewood Drive, Danvers, MA 01923. Payment may also be made electronically through CCC Online at copyright.com. Other copying for republication, resale, advertising or promotion, or any form of systematic or multiple reproduction of any material in this book is prohibited except with permission in writing from the publisher. The CCC fee code is 0277-786X/12/\$18.00.

Printed in the United States of America.

Publication of record for individual papers is online in the SPIE Digital Library.

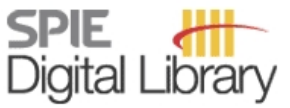

SPIEDigitalLibrary.org

Paper Numbering: Proceedings of SPIE follow an e-First publication model, with papers published first online and then in print and on CD-ROM. Papers are published as they are submitted and meet publication criteria. A unique, consistent, permanent citation identifier (CID) number is assigned to each article at the time of the first publication. Utilization of CIDs allows articles to be fully citable as soon as they are published online, and connects the same identifier to all online, print, and electronic versions of the publication. SPIE uses a six-digit CID article numbering system in which:

- The first four digits correspond to the SPIE volume number.

- The last two digits indicate publication order within the volume using a Base 36 numbering system employing both numerals and letters. These two-number sets start with $00,01,02,03,04$, $05,06,07,08,09,0 A, 0 B \ldots 0 Z$, followed by 10-1Z, 20-2Z, etc.

The CID number appears on each page of the manuscript. The complete citation is used on the first page, and an abbreviated version on subsequent pages. Numbers in the index correspond to the last two digits of the six-digit CID number. 


\section{Contents}

ix Conference Committee

\section{NANOWIRE, NANOTUBE, AND NANOSTRUCTURES I}

834403 Nanostructured materials for multifunctional applications under NSF-CREST research at Norfolk State University (Invited Paper) [8344-02]

A. K. Pradhan, R. Mundle, K. Zhang, T. Holloway, O. Amponsah, D. Biswal, R. Konda, C. White, H. Dondapati, K. Santiago, T. Birdsong, M. Arslan, B. Peeples, D. Shaw, J. Smak,

C. Samataray, M. Bahoura, Norfolk State Univ. (United States)

834404 Development and investigation of flexible polymer neural probe for chronic neural recording [8344-03]

C. Smith, K. D. Song, H. Yoon, Norfolk State Univ. (United States); W.-K. Kim, T. Zeng,

L. D. Sanford, Eastern Virginia Medical School (United States)

\section{NANOWIRE, NANOTUBE, AND NANOSTRUCTURES II}

834409 Carbon nanotube based composite fibers for strain sensing, signal processing, and computing [8344-08]

H. Vardhan, D. Roy Mahapatra, Indian Institute of Science (India)

\section{NANO DEVICES AND SENSORS I}

8344 OA Al-doped ZnO aligned nanorod arrays for opto-electronic and sensor applications [8344-09]

T. Holloway, R. Mundle, H. Dondapati, R. B. Konda, M. Bahoura, A. K. Pradhan, Norfolk State Univ. (United States)

$8344 \mathrm{OB}$ Acetone vapor sensor made with cellulose- $\mathrm{TiO}_{2} / \mathrm{MWCNTS}$ hybrid nanocomposite [8344-10] Y. Chen, H. Jung, J. Kim, Inha Univ. (Korea, Republic of)

8344 OC Design of nanostructured-based glucose biosensors [8344-11] A. Komirisetty, F. Williams, A. Pradhan, R. B. Konda, H. Dondapati, D. Samantaray, Norfolk State Univ. (United States)

8344 OD Mathematical simulation for integrated linear Fresnel spectrometer chip [8344-12] Y. Park, National Institute of Aerospace (United States); H. Yoon, Norfolk State Univ. (United States); U. Lee, Gacheon School of Medicine (Korea, Republic of); G. C. King, S. Choi, NASA Langley Research Ctr. (United States) 
8344 OE Smart healthcare textile sensor system for unhindered-pervasive health monitoring [8344-13]

P. Rai, P. Kumar, S. Oh, H. Kwon, Univ. of Arkansas (United States); G. N. Mathur,

V. K. Varadan, Univ. of Arkansas (United States) and Global Institute of Nanotechnology

(United States); M. P. Agarwal, Global Institute of Nanotechnology (United States)

8344 OF The Zigbee wireless ECG measurement system design with a motion artifact remove algorithm by using adaptive filter and moving weighted factor [8344-62]

H. Kwon, S. Oh, Univ. of Arkansas (United States); V. K. Varadan, Univ. of Arkansas (United

States), Pennsylvania State Univ. (United States), and Global Institute of Nanotechnology in

Engineering and Medicine Inc. (United States)

\section{KEYNOTE LECTURE III}

8344 OG Printed hybrid systems (Keynote Paper)[8344-14]

P. Karioja, J.-T. Mäkinen, K. Keränen, J. Aikio, T. Alajoki, T. Jaakola, M. Koponen, A. Keränen, M. Heikkinen, M. Tuomikoski, R. Suhonen, L. Hakalahti, P. Kopola, J. Hast, R. Liedert,

J. Hiltunen, N. Masuda, A. Kemppainen, K. Rönkä, R. Korhonen, VTT Technical Research Ctr. of Finland (Finland)

$8344 \mathrm{OH}$ Synthesis and characterization of thermoelectric ink for renewable energy applications [8344-15]

J. Lee, Univ. of Arkansas (United States); H. J. Kim, NASA Langley Research Ctr. (United States); S. Oh, Univ. of Arkansas (United States); S. H. Choi, NASA Langley Research Ctr. (United States); V. K. Varadan, Univ. of Arkansas (United States)

\section{NANO DEVICES AND SENSORS II}

8344 Ol Cellulose-gold nanowire (GNW) composite for electronic applications [8344-16] J.-H. Kim, B. Lim, Chosun Univ. (Korea, Republic of); S. Park, Sungshin Women's Univ. (Korea, Republic of)

8344 0J Titanium dioxide-cellulose hybrid nanocomposite based conductometric glucose biosensor [8344-17]

M. Maniruzzaman, S. K. Mahadeva, A. H. Khondoker, J. Kim, Inha Univ. (Korea, Republic of)

$8344 \mathrm{OL}$ Lithium iron phosphates as cathode materials in lithium ion batteries for electric vehicles [8344-19]

G. Wang, Shaoxing Univ. (China) and Univ. of Arkansas (United States); L. Chen,

G. N. Mathur, V. K. Varadan, Univ. of Arkansas (United States)

\section{SMART ELECTRONICS}

834400 Electronic current transport in CNT-FETs for operation in ballistic region [8344-22] A. Srivastava, Y. Xu, Louisiana State Univ. (United States); A. K. Sharma, C. Mayberry, Air Force Research Lab. (United States) 
8344 OR Music close to one's heart: heart rate variability with music, diagnostic with e-bra and smartphone (Invited Paper) [8344-25]

S. Hegde, National Institute of Mental Health and Neuro Sciences (India); P. S. Kumar, P. Rai, Univ. of Arkansas (United States); G. N. Mathur, Univ. of Arkansas (United States) and Global Institute of Nanotechnology in Engineering and Medicine Inc. (United States),

V. K. Varadan, Univ. of Arkansas (United States), Pennsylvania State Univ. (United States), and Global Institute of Nanotechnology in Engineering and Medicine Inc. (United States)

8344 OS Wireless power using magnetic resonance coupling for neural sensing applications [8344-26]

H. Yoon, Norfolk State Univ. (United States); H. Kim, S. H. Choi, NASA Langley Research Ctr. (United States); L. D. Sanford, Eastern Virginia Medical School (United States); D. Geddis, Norfolk State Univ. (United States); K. Lee, Federal Highway Administration (United States); J. Kim, Inha Univ. (Korea, Republic of); K. D. Song, Norfolk State Univ. (United States)

8344 OT Wireless structural sensor made with frequency selective surface antenna [8344-27] S.-D. Jang, J. Kim, Inha Univ. (Korea, Republic of)

8344 OU Wireless brain-machine interface using EEG and EOG: brain wave classification and robot control [8344-28]

S. Oh, P. S. Kumar, H. Kwon, Univ. of Arkansas (United States); V. K. Varadan, Univ. of Arkansas (United States), Pennsylvania State Univ. (United States), and Global Institute of Nanotechnology in Engineering and Medicine Inc. (United States)

8344 OV A film-type haptic actuator for mobile devices [8344-29]

D.-G. Kim, Inha Univ. (Korea, Republic of); S.-Y. Kim, Korea Univ. of Technology and Education (Korea, Republic of); K.-B. Kim, J. Kim, Inha Univ. (Korea, Republic of)

\section{FABRICATION AND CHARACTERIZATION I}

8344 OW New technologies for large-scale micropatterning of functional nanocomposite polymers (Invited Paper) [8344-30]

A. Khosla, B. L. Gray, Simon Fraser Univ. (Canada)

8344 OX Effect of rare earth elements (Er, Ho) on semi-metallic materials (ScN) in an applied electric field [8344-31]

H. Kim, Y. Park, National Institute of Aerospace (United States); G. C. King, NASA Langley Research Ctr. (United States); K. Lee, Federal Highway Administration (United States);

S. H. Choi, NASA Langley Research Ctr. (United States)

\section{FABRICATION AND CHARACTERIZATION II}

$8344 \mathrm{OZ} \quad$ Electromagnetic characteristics of carbon nanotubes with strain [8344-33]

B. Javvaji, S. Raha, D. Roy Mahapatra, Indian Institute of Science (India) 
834411 Covalent functionalization of carbon nanotube forests grown in situ on a metal-silicon chip [8344-35]

J. R. Johansson, N. Bosaeus, N. Kann, B. Åkerman, B. Nordén, Chalmers Univ. of Technology (Sweden); W. Khalid, Chalmers Univ. of Technology (Sweden), Jadoo Technologies Inc.

(Canada), and Univ. of California, Berkeley (United States)

834413 Preparation and characterization of nano-composites with carbon nanotubes and core-shell type polyaniline for the conductive colloidal ink [8344-37]

J. Lee, V. K. Varadan, Univ. of Arkansas (United States)

\section{FABRICATION AND CHARACTERIZATION III}

834415 Fabrication of paper-like ZnO-cellulose hybrid nanocomposite [8344-39]

H.-U. Ko, Inha Univ. (Korea, Republic of); B. Lim, J.-H. Kim, Chosun Univ. (Korea, Republic of):

J. Kim, Inha Univ. (Korea, Republic of)

834416 Synthesis and characterization of functionalized magnetic nanoparticles [8344-40]

D. Biswal, B. N. Peeples, D. D. Spence, C. Peeples, C. N. Bell, A. K. Pradhan, Norfolk State Univ. (United States)

834417 Effectiveness of multiple pulses on flow index of electroporation [8344-41]

B. I. Morshed, Univ. of Memphis (United States); M. Shams, Carleton Univ. (Canada);

T. Mussivand, Univ. of Ottawa (Canada)

\section{FABRICATION AND CHARACTERIZATION IV}

834418 Thermal effects of X-band microwaves on skin tissues [8344-42]

K. D. Song, H. Yoon, Norfolk State Univ. (United States); K. Lee, Inha Univ. (Korea, Republic of);

J. Kim, Federal Highway Administration (United States); S. H. Choi, NASA Langley Research

Ctr. (United States)

834419 Microfluidics on compliant substrates: recent developments in foldable and bendable devices and system packaging [8344-43]

B. L. Gray, Simon Fraser Univ. (Canada)

8344 IA Fabrication of IDT electrode onto cellulose electro-active paper by inkjet printing [8344-44] S. Mun, L. Zhai, H. Jung, J. Kim, Inha Univ. (Korea, Republic of)

8344 1B Development of a phase modulation surface plasmon resonance image detection system based on time-stepped quadrature phase shifting method [8344-45]

S.-S. Lee, T.-Y. Huang, S.-E. Chen, C.-C. Hung, National Taiwan Ocean Univ. (Taiwan)

\section{APPLICATIONS I}

8344 ID Determination of effective boundaries and material properties of SRR-rod and fishnet metamaterials [8344-47]

F.-J. Hsieh, Univ. of Washington (United States); W.-C. Wang, Univ. of Washington (United

States) and National Cheng Kung Univ. (Taiwan) 
8344 IE Nondestructive methods to assess dental implant stability [8344-48]

P. Rizzo, A. Tabrizi, B. Berhanu, M. W. Ochs, Univ. of Pittsburgh (United States)

8344 IG Medical CT image reconstruction accuracy in the presence of metal objects using $x$-rays up to $1 \mathrm{MeV}$ with $\mathrm{x}$-ray targets of beryllium, carbon, aluminum, copper, and tungsten [8344-50]

J. Clayton, A. Ganguly, G. Virshup, Varian Medical Systems (United States)

$8344 \mathrm{lH}$ Investigation of coplanar strip dipole rectenna elements for microwave power transmission: simulation and experiment [8344-51]

S. Y. Yang, Inha Univ. (Korea, Republic of); K. D. Song, H. Yoon, Norfolk State Univ. (United States); J. Kim, Inha Univ. (Korea, Republic of)

834411 Predicting brain tissue deformation around an implantable electrode due to dynamic micromotion [8344-52]

M. Polanco, Old Dominion Univ. (United States); H. Yoon, Norfolk State Univ. (United States);

K. Lee, S. Bawab, Old Dominion Univ. (United States)

8344 1J Size and shape dependence of the electrochemical properties of hematite nanoparticles and their applications in lithium ion batteries [8344-53]

L. Chen, Univ. of Arkansas (United States); G. Wang, Univ. of Arkansas (United States) and Shaoxing Univ. (China); G. N. Mathur, V. K. Varadan, Univ. of Arkansas (United States)

\section{POSTER SESSION}

8344 IK A study of micro bending test for polycrystalline by modified strain gradient theory [8344-54] B.-B. Jung, H.-C. Park, Pohang Univ. of Science and Technology (Korea, Republic of)

8344 IL Synthesis and characterization of lithium ion batteries [8344-55]

A. K. Pradhan, K. Zhang, R. Mundle, M. Arslan, O. Amponsah, M. Bahoura, Norfolk State Univ. (United States)

8344 IM Remarkable evolution of electrical conductivity in Al:ZnO films [8344-56]

H. Dondapati, R. Mundle, R. B. Konda, M. Bahoura, A. K. Pradhan, Norfolk State Univ. (United States)

834410 Ultrasound contrast agent fabricated from microbubbles containing instant adhesives, and its ultrasound imaging ability [8344-58]

T. Makuta, Y. Tamakawa, Yamagata Univ. (Japan)

Author Index 
Downloaded From: https://www.spiedigitallibrary.org/conference-proceedings-of-spie on 26 Apr 2023

Terms of Use: https://www.spiedigitallibrary.org/terms-of-use 


\title{
Conference Committee
}

\author{
Symposium Chairs
}

Norbert G. Meyendorf, Fraunhofer-Institut für Zerstörungsfreie

Prüfverfahren (Germany) and University of Dayton (United States)

Norman M. Wereley, University of Maryland, College Park (United

States)

Symposium Cochairs

Victor Giurgiutiu, University of South Carolina (United States)

Christopher S. Lynch, University of California, Los Angeles (United

States)

Conference Chair

Vijay K. Varadan, University of Arkansas (United States)

Conference Cochairs

Jaehwan Kim, Inha University (Korea, Republic of)

Kyo D. Song, Norfolk State University (United States)

Sang H. Choi, NASA Langley Research Center (United States)

Yongrae Roh, Kyungpook National University (Korea, Republic of)

\section{Program Committee}

Christina Brantley, U.S. Army Research, Development and Engineering Command (United States)

Natalie Clark, NASA Langley Research Center (United States)

Kimiya Komurasaki, The University of Tokyo (Japan)

Ajit Khosla, Simon Fraser University (Canada)

Kunik Lee, Turner-Fairbank Highway Research Center (United States)

Uhn Lee, Gachon University Gil Medical Center (Korea, Republic of)

Xinxin Li, Shanghai Institute of Microsystem and Information

Technology (China)

Yanjian Liao, Chongaing University (China)

Samuel C. Lee, The University of Oklahoma (United States)

D. Roy Mahapatra, Indian Institute of Science (India)

Yeonjoon Park, National Institute of Aerospace (United States)

Parag Ganapathi Patil, University of Michigan Health System (United States)

II-Kwon Oh, KAIST (Korea, Republic of)

Aswini K. Pradhan, Norfolk State University (United States) 
Paul Ruffin, U.S. Army Armament Research, Development and Engineering Center (United States)

Ashok Srivastava, Louisiana State University (United States)

Tauno Vaha-Heikkila, VTT Technical Research Center of Finland

(Finland)

Richard K. Watt, Brigham Young University (United States)

Hargsoon Yoon, Norfolk State University (United States)

T. C. Yih, Oakland University (United States)

Ming Zhou, Suzhou Institute of Nano-tech and Nano-bionics (China)

\section{Session Chairs}

1 Keynote Lecture I

Vijay K. Varadan, University of Arkansas (United States)

2 Nanowire, Nanotube, and Nanostructures I

Hargsoon Yoon, Norfolk State University (United States)

3 Keynote Lecture II

Sang H. Choi, NASA Langley Research Center (United States)

$4 \quad$ Nanowire, Nanotube, and Nanostructures II

Hyunjung Kim, National Institute of Aerospace (United States)

$5 \quad$ Nano Devices and Sensors I

Frances Williams, Norfolk State University (United States)

6 Keynote Lecture III

Vijay K. Varadan, University of Arkansas (United States)

$7 \quad$ Nano Devices and Sensors II

Christina Brantley, U.S. Army Research, Development and Engineering Command (United States)

8 Keynote Lecture IV

Sang H. Choi, NASA Langley Research Center (United States)

9 Smart Electronics

Ashok Srivastava, Louisiana State University (United States)

10 Wireless Sensor System

Eugene Edwards, U.S. Army Research, Development and Engineering Command (United States)

11 Fabrication and Characterization I

Bonnie L. Gray, Simon Fraser University (Canada) 
12 Fabrication and Characterization II

Vijay K. Varadan, University of Arkansas (United States)

13 Fabrication and Characterization III

Joo-Hyung Kim, Chosun University (Korea, Republic of)

14 Fabrication and Characterization IV

Vijay K. Varadan, University of Arkansas (United States)

15 Applications I

Vijay K. Varadan, University of Arkansas (United States)

16 Applications II

Hyunjung Kim, National Institute of Aerospace (United States) 
Downloaded From: https://www.spiedigitallibrary.org/conference-proceedings-of-spie on 26 Apr 2023

Terms of Use: https://www.spiedigitallibrary.org/terms-of-use 